\title{
Associative experiment in the study of the key concept IRELAND
}

\author{
D. V. Polhorodnyk
}

Zaporizhzhya National University, Zaporizhzhya, Ukraine

Corresponding author. E-mail: polgorodnyk@outlook.com

Paper received 27.10.19; Accepted for publication 15.11.19.

\section{https://doi.org/10.31174/SEND-Ph2019-211VII62-09}

\begin{abstract}
The Anglo-Irish worldview was formed during the continuous linguistic and cultural interaction of autochthonous Celtic and imported Anglo-Saxon linguocultures. The prolonged contact influenced the formation of a new Anglo-Irish linguoculture with a number of cultural keywords. It is determined that IRELAND is a key concept of the Anglophone worldview in Ireland. This concept has an extensive nomination system with two key names - Ireland and Eire. Free and directed associative experiments allow to identify important information regarding the emotional and evaluative plane of conceptualization.
\end{abstract}

Keywords: key concept, Anglo-Irish linguoculture, free associative experiment, directed associative experiment, conceptual properties.

Introduction. Contemporary linguistics pays significant attention to the problems of interrelation between languages, cultures, ethnic awareness, as well as to the formations of national worldviews and their objectivization. The development of any society is accompanied by the linguocultural contact. Modern English is a result of numerical linguistic and cultural contacts that is characterized by significant variety of national variants, social and territorial dialects. The English language in the Republic of Ireland was developing during continuous coexistence of the Anglo-Saxon and the Celtic elements, which influenced on all the levels of the language system. This contact had a great impact on social conscience, linguistic and cultural competences; it was reflected in the conceptual and linguistic worldviews, contributing to the structure and meaning of the concepts.

Previous publications review. According to S.G. Vorkachev [3, p. 113], "the concept is able to reflect in its semantics the national mentality as a set of ideological and behavioural features of the ethnic group and the national character as a stable and integral composition of the mental life of the linguistic personality, which determines its originality - its ethnicity." Cultural concepts capture the specificity of a particular culture [5, p. 29] and the worldview of its carriers. Therefore, in each language there is a set of semantically loaded words that designate meaningful, culture-specific components of the worldview and are more influential in comparison with other nominations. Some scholars emphasize that these words express the key ideas of linguistic culture: "key concepts of culture" (V.A. Maslova [8]), "keywords of language" (A. Wierzbicka [2]). Other scientists emphasize the evaluative component of words and concepts denoted by them, which form a certain type of culture ("cultural dominants" (V.I. Karasik [6]). $\mathrm{Yu}$. S. Stepanov focuses attention on the historical stability of concepts ("culture constants" [9, p. 6]).

Important criteria for identifying a concept include fixed name [7, p. 56]; its continuance [9, p. 84]; frequency of appeal to the concept; socio-cultural value of the concept [7, p. 56]. The concept IRELAND meets all of the above criteria. This concept has an extensive nomination system with two key names - English (Ireland) and Irish (Eire) based; each of which obviously has a number of functions and associations.

Despite the multifaceted study of the structure and functioning of the English language in Ireland (T. P. Dolan, J.
L. Kallen, B. Ó Cuív, R. Hickey, O. I. Abramova, O. I. Doroshenko), only few studies deal with the formation of concepts of Anglo-Irish culture (a comparative analysis of the actualization of concepts WONDER in Russian and MIRACLE in Anglo-Irish [1], a research on features of individual and author concepts of J. Joyce [4]). Nevertheless, the study of concepts was conducted only on materials of literary writings. Analysis of semantics and contextual analysis is incapable of providing a complete picture of conceptualization. Although dictionaries of various types and literary sources reflect actualization of the concept, important information regarding the emotional and evaluative plane of conceptualization remains unnoticed by the researchers.

The research aims to establish the cognitive attributes of the concept IRELAND that are relevant to the bearers of the contemporary Anglo-English worldview through the associative experiment.

Materials and methods. The study involved conducting free and directed associative experiments, supplemented with sociolinguistic questionnaires to ensure the representativeness of the research.

The method of a free associative experiment is that the respondents are offered stimulus words, to which they must respond with verbal forms that come to their mind (What associations do you have with the word Ireland/Eire?).

The purpose of a directed associative experiment is to study the knowledge and understanding of the meaning of the linguistic unit by native speakers. The directed associative experiment allowed the informants to fill in the gaps in the text fragments with the words Ireland or Eire (Which word Ireland or Eire best fits the following sentences?). The total number of contexts from nonfiction and fiction sources was 16 pieces.

The experiment was conducted in Dublin, Galway, Skerris, Ireland in 2016. The experiment involved 200 participants (114 men and 86 women) who consider themselves Irish, living in the Republic of Ireland, aged from 20 to 74. The level of education of informants varied (complete secondary education, bachelor, master, doctor of philosophy). Representatives of different professions participated in the experiment: students of the university, teachers of higher educational establishments, teachers of secondary schools, scientists, workers, unemployed, etc. 
The associative experiments revealed a number of associates of the concept IRELAND, characterising their distribution between the two key names - Ireland and Eire.

Results and discussion. Approximately the same amount of associative reactions (304 for Ireland and 302 for Eire) were obtained. This testifies to the relevance of both Anglo-Saxon and Celtic elements in the English language of Ireland. The number of associations for Ireland is 56, for Eire -57 , which also confirms the development of both areas.

The analysis of the obtained results made it possible to distinguish the conceptual properties of the key names of the concept and allowed to combine the results on a denotative basis. Single associations (car, star, memory, neutral) are considered to be individual and not characterizing the collective linguistic consciousness of native Anglo-Irish linguoculture.

The conceptual properties that verbalize the sphere Ireland according to the associative experiment are 'country, state' (112), 'cultural space' (93), 'dry land' (75), 'land of ancestors' (20), 'human being' (4). On the other hand, the sphere Eire is characterised by 'cultural space' (142), 'country, state' (92), 'land of ancestors' (44), 'dry land' (24), 'human being' (2). In the context of the aforementioned general properties, it is possible to distinguish more narrow ones.

In the sphere of Ireland within the conceptual property 'country, state' (112) the following reactions are observed:

- political space (state "a country or its government" [11], country "an area of land that has its own government, army" [11]);

- specific state (Eire "the name for Ireland in Irish" [11], the South, Southern Ireland "part of Ireland - 'Irish Free State' with a devolved parliament in Dublin" [17]);

- political leader (sovereign "a king or queen" [11], Enda Kenny "Taoiseach after the 2011 elections" [15]);

- political system (republic "a country without a king or queen, usually governed by elected representatives of the people and a president" [11], Home Rule "a political arrangement in which a part of a country governs itself independently of the central government of the country" [11]);

- foreign policy (Europe "the European Union" [11], diplomacy "the management of relationships between countries" [11]);

- economic and political centres (Dublin "city, capital of Ireland" [15], Galway "city, seaport, and county town (seat) of County Galway" [15], Cork "seaport and seat of County Cork, in the province of Munster" [15]);

- legal relations (justice "the system of laws in a country that judges and punishes people" [11], constitutional "allowed by or contained in a constitution" [11], freedom "the condition or right of being able or allowed to do, say, think, etc. whatever you want to, without being controlled or limited" [11], garda "the police force of the Republic of Ireland" [11]).

It is noteworthy that the conceptual property 'cultural space' (93) is significant, since cultural realities, values and symbols are of particular importance:

- national symbols (shamrock "a plant that has become a special symbol of Ireland" [16, c. 18], tricolor "a flag that is divided into three equal parts of different colour" [11]);

- musical culture (harp "a large, wooden musical instrument with many strings" [11], music "a pattern of sounds made by musical instruments, voices" [11], jig "an energetic traditional dance of Great Britain and Ireland, or the music that is played for such a dance" [11]);

- sports culture (football "a game played between two teams" [11], hurling "a field game played with hurleys and a sliotar" [14, c. 124], the League of Ireland "the national association football league of Ireland" [15]);

- 'pub culture' (pub “a place, especially in Great Britain or Ireland, where alcoholic drinks can be bought and drunk and where food is often available" [11], Guinness "brewer of a distinctive dark and creamy stout" [15], stew "a type of food consisting usually of meat or fish and vegetables cooked slowly in a small amount of liquid" [11], stout "a dark, bitter type of beer" [11]);

- mythological realia (leprechaun "a magical creature in the shape of a little old man who likes to cause trouble" [11]);

- religious component (St Patrick's Day “feast day of St. Patrick, patron saint of Ireland" [15], cross "a symbol of Christianity" [11]);

- material and cultural values (culture "the way of life, especially the general customs and beliefs, of a particular group of people at a particular time" [11], castle "a large strong building, built in the past" [11], poetry "poems in general as a form of literature" [11], mill "a building where grain is crushed into flour" [11]).

Speaking of the conceptual property 'dry land' (75), Ireland is:

- island (island, Emerald Isle "a piece of land completely surrounded by water" [11]);

- part of a mainland (Europe "the continent that is to the east of the Atlantic Ocean, to the north of the Mediterranean, and to the west of Asia" [11]);

- territory with specific landscape (mountain "a raised part of the earth's surface" [11], Irish Sea "the sea between Britain and Ireland" [11], bog "soft, wet ground" [11], pebble "a small smooth round stone" [11]);

- territory with specific nature (green "covered with grass, trees, and other plants" [11], nature "all the animals, plants, rocks, etc. in the world" [11]);

- territory with specific climate (rainy, rain "drops of water from clouds" [11]).

Within the conceptual property 'land of ancestors' (20), people's awareness of their national identity draws attention to:

- nationality (nation "large group of people of the same race who share the same language, traditions, and history" [11], nationhood "the fact of being a nation" [11]);

- common ancestor (Celts "a person who is related to the Celts" [11]);

- patriotism (Easter Rising "Irish republican insurrection against British government" [15]).

The least representative and fragmentary is the conceptual property 'human being' (4), which reflects the connection between the state and its personalized image (emotions "strong feelings in general" [11], life "the experience or state of being alive" [11], related "belong to the same family" [11], family "a group of people who are related to each other" [11]).

Upon analysing the data obtained for the name of the concept Eire, we state the exceptional relevance of the 'cultural space' (149). Native speakers of English-Irish linguoculture note: 
- long, forgotten history (history "past events considered together, especially events of a particular period, country, or subject" [11], past "used to refer to a period of time before and until the present" [11], old "having lived or existed for many years" [11], lost "unable to be found" [20], forgotten "to be unable to remember a fact, something that happened, or how to do something" [11], ancient "of or from a long time ago, having lasted for a very long time" [11], distant "far away" [11]);

- specific language (Gaelic revival, Celtic revival "resurgence of interest in Irish language, literature, history, and folklore" [15], Gaelic speakers "speakers of the Irish language" [15], Gaeltacht "areas in which the Irish language and the traditional national culture are best preserved" [15]);

religious component (Padraig - Irish variant of the name Patrick (Saint Patrick), faith "a particular religion" [11], Trinity "in Christianity, the existence of one God in three forms, the Father, the Son, and the Holy Spirit" [11]);

- cultural heroes (hero "a person who is admired for having done something very brave or having achieved something great" [11], Big Fellow "Michael Collins - an Irish revolutionary, soldier and politician" [19], Eriu "Irish goddess" [12], Connolly "Marxist union leader and revolutionary who was a leading participant in the Easter Rising" [15], Cuchulainn "the central character of the Ulster cycle in medieval Irish literature, the greatest of the Knights of the Red Branch" [15]);

- 'pub culture' (Guinness);

- sports culture (hurling);

- national symbols (shamrock);

- documents, regulations (official documents "having the approval or authorization of an authority or public body" [20], governmental documents "relating to or denoting the government of a country or state" [20], manuscript "an old document or book" [11]).

Another relevant conceptual property is 'country, state' (145). Respondents noted that Eire is:

- political space (state);

- specific state (Ireland "a country in western Europe occupying the southern part of the island of Ireland" [11], Poblacht na hEireann "Irish Republic" [311], Irish Free State "state created under Anglo-Irish Agreement" [13], 26 Counties "the Irish state represented by 26 counties" [21, c. 1053], Erin "archaic or literary name for Ireland" [20]);

- has a particular state structure (Sinn Fein "an Irish political party that wants Northern Ireland to become part of the Republic of Ireland" [11], Taoiseach, Dail Eireann "Irish Assembly" [15], Republicanism "support for a republican system of government" [20]);

- participant of a military conflict (revolution "a change in the way a country is governed, usually to a different political system and often using violence or war" [11], war "armed fighting between two or more countries or groups" [11], Civil war "a war fought by different groups of people living in the same country" [11]);

- centralized state (Dublin);

- has a political leader (Eamon de Valera "Irish politician and patriot, who served as taoiseach" [15]);

- with a legal system (garda).

The conceptual property 'land of ancestors' (44) is represented by the following associations:
- patriotism (nationalism "a nation's wish and attempt to be politically independent" [11], 1916, Easter Rising);

- ancestors (grandmother "the mother of a person's father or mother" [11], ancestry "a person related to you who lived a long time ago" [11]).

As 'dry land' (24) Eire is viewed as:

- island (Emerald Isle, Inisfail "the island of Ireland" [18]);

- territory with specific landscape (lough "a lake or an inlet" [11], cnoc "hill" [18], stone "the hard, solid substance found in the ground" [11], glas "stream" [18]);

- territory with floral component (green, ivy "an evergreen plant" [11], oak "a large tree" [11]).

Understanding of Eire as 'human being' (2) with the association rua ("red-headed, red-haired" [18]) is not relevant.

The directed associative experiment showed that the informants had presented the same amount of associations. However, they are not symmetrical and are actualized in different ways.

- in situations where a positive attitude towards Ireland is shown ("I meant to say, that ... had been a friend to me", "I would, before my time to go, Sing of old ... and the ancient ways"), the informants (53\%) preferred the word Ireland;

- in the examples where Ireland is recognized as a home country, land, motherland ("If there is one country I feel at home in, it is ...", "We would not give up our own country - ") the word Eire (43\%) predominates;

- for characterizing statehood ("Our vision for ... is [of] a secular, inclusive, multilingual, comfident State.", "I could not now write of any other country but ..., for my style has been shaped by the subjects I have worked on.”) the informant chose Ireland $(85 \%)$;

- stimulus "Ireland - a kingdom" ("I calculate my remedy for this one individual Kingdom of ..., and for no other that ever was, is, or, I think, ever can be upon Earth.") is attributed to Ireland (92\%);

- association 'an island'("Noble ..., island of kings") is a predominant reaction of the informants $(75 \%)$ for Ireland;

- understanding of Ireland as a place ("I heard the Voice, the persistent one that forced me to return here to ... the place of my captivity", "And some place called "..." is excluded from the study, on the basis that that initial analysis provided too much evidence of shared Irish ancestry") is attributed to the English variant - Ireland (78\%).

Thus, Ireland correlates with the spheres of statehood, geographical space, and Eire - home country, the land of ancestors.

Conclusions. A thorough analysis of the data obtained from the associative experiments showed that in the AngloIrish linguoculture the fields of usage of Ireland and Eire intersect, but do not overlap. The dominant field of use of the Celtic name Eire is the sphere of nationality, patriotism, historical past, certain language and religion, which can generally be described as an ethnic component and the sphere of national culture. In turn, for the English name Ireland the most relevant is the socio-political plane, namely statehood, mythology, sports, pub culture. 


\section{ЛИТЕРАТУРА}

1. Абышева Е. М. Концептуальные инверсии: концепт "чудо":на материале русских и ирландских пословиц, поговорок и сказок: дис. ... канд. филол. наук: 10.02.20. Тюмень, 2008. 20 с.

2. Вежбицкая А. Понимание культуры через пространство ключевых слов [пер. с англ. А. Д. Шмелева]. Москва: Языки слов культуры, 2001. 289 с.

3. Воркачев С. Г. «Счастье» как лингвокультуный концепт. Москва: Гнозис, 2004. 192 с.

4. Горбунова Н. Г. Языкотворчество Дж. Джойса: словообразовательный аспект (на примере романа "Улисс"): дисс.... канд. филол. наук.: 10.02.04. СПб, 2005. 204 с.

5. Карасик В. И. Зеркальный концепт «Простота». Новое в когнитивной лингвистике: материальл междунар конф./отв. ред. М. В. Пименова. Кемерово: КемГУ, 2006. Вып. №8. С. 26-41.

6. Карасик В. И. Концепт как категория. Известия Волгоградского государственного педагогического ун-та. Волгоград: ГОУ ВПО ВГПУ, 2002. Серия «Филологические науки». №1. С. 14-23.

7. Карасик В. И. Концепты-релятивы. Язык, сознание, коммуникация/Отв. ред. В. В. Красных, А. И. Изотов. Москва: МАКС Пресс, 2005. Вып. 30. С. 95-108.

8. Маслова В. А. Лингвокультурология. Москва: Издат. центр. «Академия», 2001. 208 с.

9. Степанов Ю. С. Константы. Словарь русской культуры. Москва: Языки русской культуры, 1997. 824 с.

10. Bunreacht na hÉireann. Constitution of Ireland - Dublin: The Stationery Office, 2013. 239 p.
11. Cambridge Dictionaries online. URL: https://dictionary.cambridge.org/ (access date 01.09.2017).

12. Daimler M. Pagan Portals - Gods and Goddesses of Ireland: A Guide to Irish Deities. https://books.google.com.ua/books?id=x-udDQAAQBAJ (access date 21.11.2017).

13. Documents on Irish Foreign Policy. The Anglo-Irish Treaty. December 1920 - December 1921 [Electronic resource]. URL: http://www.difp.ie/documents/1921treaty.pdf (access date 01.09.2017).

14. Dolan T. P. A Dictionary of Hiberno-English. 3rd edition. Dublin: Gill \& MacMillan, 2014. xxviii, 320 p.

15. Encyclopedia Britannica [Electronic resource]. URL: https://www.britannica.com/ (access date 01.09.2017).

16. Fazzi C. How to Draw Ireland's Sights and Symbols. New York, 2005. 48 p.

17. Government of Ireland Act 1920 [Electronic resource]. URL: http://www.legislation.gov.uk/ukpga/1920/67/pdfs/ukpga_19200067_en.pdf (access date 01.09.2017).

18. New Irish-English Dictionary. URl: https://www.teanglann.ie/en/ (access date 02.04.2017).

19. O'Connor F. The Big Fellow: Michael Collins and the Irish Revolution. Stuttgart, 1998. 224 p.

20. Oxford Dictionaries Online. URL: http://www.oxforddictionaries.com/ (access date 01.09.2017).

21. Paxton J. The Statesman's Year-Book 1976-77. New York, 2016. $1644 \mathrm{p}$

\section{REFERENCES}

1. Abysheva E. M. The Conceptual Inversions: the Concept of Miracle (on the Material of Russian and Irish Proverbs, Sayings and Fairy Tales). Cand. philol. sci. abs. diss. Tyumen, 2008. 20 p.

2. Wierzbicka A. Understanding Cultures through Their Key Words. Moscow: Yazyki slov kul'tury, 2001.289 p.

3. Vorkachev S.G. "Happiness" as a Linguocultural Concept". Moscow: Gnozis, 2004. 236 p.

4. Gorbunova N. G. Linguistics of J. Joyce: the word-formation aspect (on the example of the novel "Ulysses "). Cand. philol. sci. diss. St. Petersburg, 2005.204 p.

5. Karasik V. I. Mirror concept simplicity. New in cognitive linguistics/ed. M.V. Pimenova. Kemerovo: KemGU, 2006. Issue Number 8. P. 26-41.

6. Karasik V. I. The concept as a category. Bulletin of the Volgograd State Pedagogical University. Volgograd: GOU VPO VGPU, 2002. Series "Philological Sciences". No. 1. P. 14-23.

7. Karasik V. I. Concepts of relativity. Language, consciousness, communication/ed. V. V. Krasnykh, A. I. Izotov. Moscow: MAKS Press, 2005. Issue. 30. P. 95-108.

8. Maslova V. A. Linguoculturology. Moscow: Publisher. center. "Academy", 2001. 208 p.

9. Stepanov Yu. S. Constants. Dictionary of Russian culture. Moscow: Yazyki russkoy kul'tury, 1997.824 p. 